\title{
EFFECTS OF VERTICAL GREEN TECHNOLOGY ON BUILDING SURFACE TEMPERATURE
}

\author{
I. BLANCO ${ }^{1}$, E. SCHETTINI ${ }^{2}$ \& G. VOX SO $^{3}$ \\ Department of Agricultural and Environmental Science DISAAT - University of Bari, Italy.
}

\begin{abstract}
A sustainable technology for improving the energy efficiency of buildings is the use of urban greening in order to reduce the energy consumption for air conditioning in summer and to increase the thermal insulation in winter. A worldwide growing interest in urban green is encouraging the application of the greening technology for more sustainable buildings. Building indoor air temperature depends on several different parameters related to the climate of the region, the building itself and its use. The main parameters influencing the microclimate are: external air temperature and relative humidity, incident solar radiation, long wave radiation exchange between the building surfaces and its surroundings, wind velocity and direction, air exchanges, physical and thermal properties of the building's envelope materials, design variables such as building dimensions and orientation, presence of artificial light, electrical equipment. Green façades can allow the physical shading of the building and promote evapotranspiration in summer and increase the thermal insulation in winter. External wall surface temperature is a parameter useful to assess the effectiveness of green façades. An experimental test was carried out at the University of Bari (Italy) for three years. Three vertical walls, made with perforated bricks, were tested: two were covered with evergreen plants (Pandorea jasminoides variegated and Rhyncospermum jasminoides) while the third wall was kept uncovered and used as control. Several climatic parameters concerning the walls and the ambient conditions were collected during the experimental test. The experimental data were used for developing a multiple regression equation regarding the dependence of the difference of external surface temperature between the green façades and the control wall and the weather conditions. The model shows a good predicting ability.
\end{abstract}

Keywords: air-conditioning, energy savings, green walls, regression model, urban agriculture, urban heat island.

\section{INTRODUCTION}

Urban Green Infrastructures (UGI) contribute to improving urban climate and reducing urban air temperature, maximum surface temperature and surface temperature variation especially in regions characterized by Mediterranean climate [1]-[5].

A worldwide growing interest in urban greenery is stimulating the application of the greening technology for more sustainable buildings [6]-[8]. The urban greening allows to improve the energy efficiency of buildings by reducing the energy consumption for air conditioning in summer and by increasing the thermal insulation in winter [9]-[15]. Building indoor air temperature depends on several different parameters related to the climate of the region, the building itself and its use. The main parameters influencing the microclimate are: external air temperature and relative humidity, incident solar radiation, long wave radiation exchange between the building surfaces and its surroundings, incidence and speed of the wind, air exchanges, physical and thermal properties of the building's envelope materials, design variables, such as building dimensions and orientation, presence of artificial light, electrical equipment.

\footnotetext{
${ }^{1}$ ORCID: http://orcid.org/0000-0003-2927-3427

${ }^{2}$ ORCID: http://orcid.org/0000-0002-8456-8677

${ }^{3}$ ORCID: http://orcid.org/0000-0003-4017-5174
} 
UGI include engineered options such as vertical greenery systems in a building that are a rising strategy in high-density urban development with scarce green areas and limited open ground space [1], [15]-[17].

Green façades and living walls are vertical greenery systems [18]-[19]. The green façade is characterized by the growing media staying on the ground at the base of the building or at different heights of the façade and by plants growing vertically in order to cover the vertical building surfaces [13]-[20]. The presence or absence of a support leads to a further distinction in direct and indirect façade. In the direct green façade (or traditional green façade), plants climb directly on the façade of the building due to their morphological features. In the indirect green façade (or double-skin green façade), plants are supported by a structure such as mesh, wire, trellis, which can be located on a free-standing system, such as fence or columns or even to a short distance from the wall [16]-[21]. The living wall has the growing media standing vertically in front of the vertical surface [13]. The living wall can be fixed to a wall or to a free-standing frame [17], [20], [22]. The living wall has major aesthetical potentialities due to the possibility of installing a wider range of plants in comparison to a green façade. The living wall is a more elaborate and costly technology, also with respect to the maintenance and energy costs [12].

Greenery vertical systems moderate the indoor thermal environment by handling the building envelope heat transfer processes (radiative, convective and conductive) [23]-[25]. The transfer of a heat wave through a vertical green is a multifaceted phenomenon due to the interposition of the plant layer between the outdoor environment and the building envelope. Green vertical systems can permit the physical shading of the building and promote evapotranspiration in summer and increase the thermal insulation in winter [26]. The external layers of a green cover behave like optical filters; the profounder layers behave like an insulation material. The leaves of the plants create a quite steady layer of air, acting as an additional thermal insulation layer that lowers the wind strength. The solar absorption coefficient value for the vertical green has been estimated to be about one third of that for an exposed bare wall. The insulating behaviour (thermal resistance) of the plant layer becomes dominant when the density of plant canopy, i.e. the covering ratio, reaches $100 \%$ [23].

Green wall thermal performance should be analysed for identifying which systems are the most effective in bringing energy savings for building cooling/heating. Energy savings heavily depend on a multitude of factors. The thermal performance of the vertical green systems in summer needs further study with reference to the relationship with the climatic conditions and to the plants that can be actually useful in a given context, in order to fill the gaps in literature. External wall surface temperature is a parameter useful to assess the effectiveness of green vertical system. It is also the most commonly observed parameter on the building or experimental prototype. Despite its evaluation does not allow adequately quantifying microclimatic benefit and thermal performance [27], it permits to compare alternative designs related to the adoption of different plant species used, or the distance of the plant layer from the wall, or the typology of building envelope.

The analysis of alternative system configurations can be evaluated using simulations in order to determine the most efficient options. Simulations can be made by different types of approaches, such as the statistical, the hybrid and the engineered ones [28]. The statistical technique called Multiple Linear Regression needs large amount of experimental data. It is ease to develop and to interpret for forecasting, in comparison to other techniques [29]. Simulation engineered models often were not validated with experimental data [2], [17], [27].

This research aims to analyse the thermal performance of two different green façades in the summer period in the Mediterranean region. An experimental test was carried out on two 
small-scale green façades at the experimental field of the University of Bari, South Italy. The effects of the greenery systems on the external surface temperature of the walls were reported. Moreover, the relationship between the external climatic conditions and the external surface temperature has been modelled on 2015 data through a regression technique. The model was validated on 2016 data. It can be used for predicting the external surface temperature reduction by the green cover.

\section{MATERIALS AND METHODS}

The experimental field of the University of Bari in Valenzano (Bari, Italy), at latitude $41^{\circ} 05^{\prime}$ $\mathrm{N}$, longitude $16^{\circ} 53^{\prime} \mathrm{E}$, altitude $85 \mathrm{~m}$ ASL, is characterized by a Mediterranean climate.

Three identical wall prototypes were built taking into consideration a typical Mediterranean building solution, i.e. a single skin of perforated bricks joined with mortar (Fig. 1). Each wall, south oriented, measured $1.00 \mathrm{~m}$ in width, with a height of $1.55 \mathrm{~m}$. The walls were $0.22 \mathrm{~m}$ thick. The masonry and the plaster coating were $0.20 \mathrm{~m}$ and $0.02 \mathrm{~m}$ thick, respectively. The average density of the walls was $695 \mathrm{~kg} \mathrm{~m}^{-3}$ (plaster included). The thermal conductivity coefficients of the masonry and the plaster coating were $0.28 \mathrm{Wm}^{-1} \mathrm{~K}^{-1}$ and $0.55 \mathrm{Wm}^{-1} \mathrm{~K}^{-1}$, respectively [28]. The heat capacity coefficient was $840 \mathrm{Jkg}^{-1} \mathrm{~K}^{-1}$ for the masonry and 1000 $\mathrm{Jkg}^{-1} \mathrm{~K}^{-1}$ for the plaster coating.

The walls were shielded and insulated on the backside with a structure made of sheets of expanded polystyrene (Fig. 1). Moreover these polystyrene structures were externally covered with a coloured net in order to reduce the effect of the incident solar radiation.

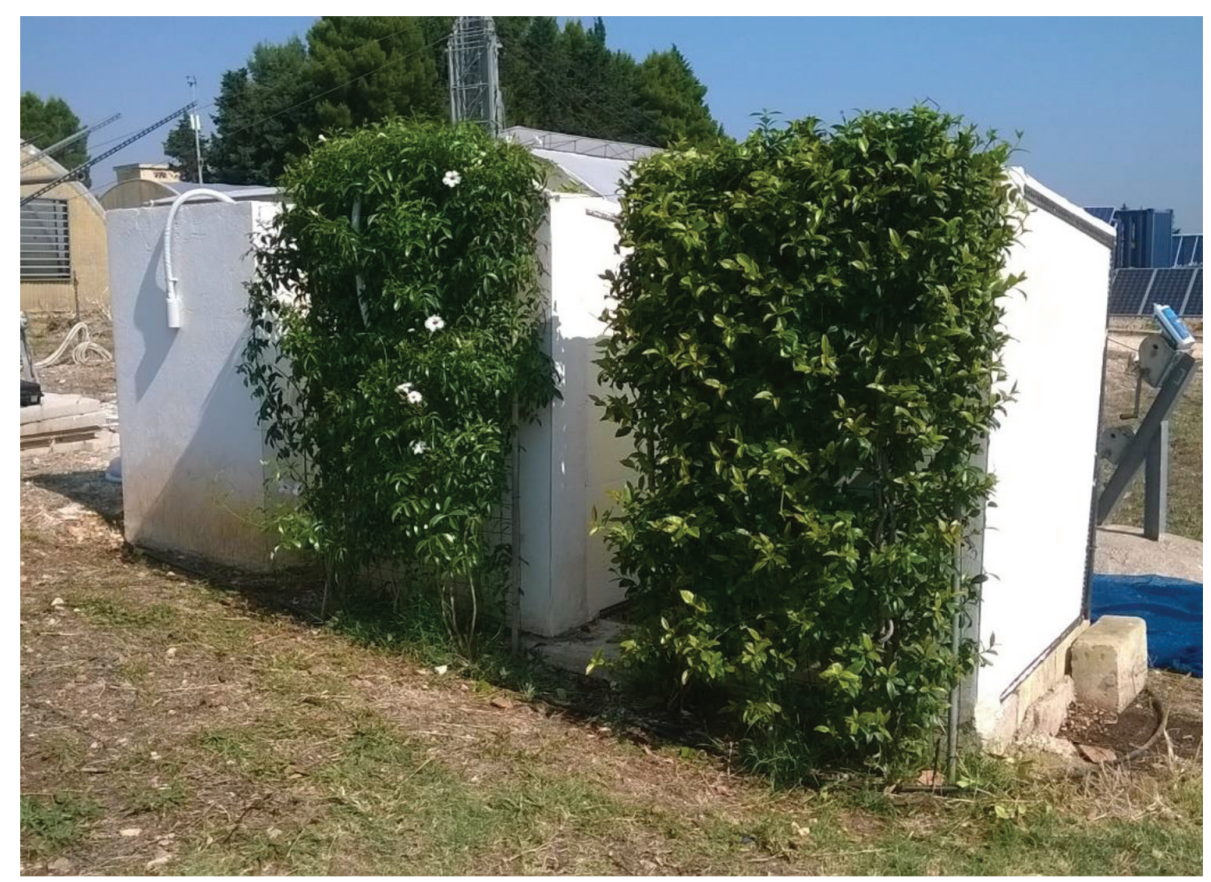

Figure 1: The experimental green façades at the University of Bari; the left wall is the reference uncovered wall, the central wall is covered with Pandorea jasminoides variegated and the right wall with Rhyncospermum jasminoides. 
One wall without plants was the reference. The other walls were covered on June 18, 2014 with an evergreen climbing plant (one with Pandorea jasminoides variegated, the other Rhyncospermum jasminoides). The plants were chosen for their suitability for Mediterranean climate. The coverage of the walls has gradually increased, starting from June 2014. An iron net was placed at a distance of $15 \mathrm{~cm}$ from the walls for supporting the plants vertical growing. The plants were irrigated with the drip system and fertilized with an N:P:K 12:12:12 fertilizer. The plants were characterized by a Plant Leaf Area Index (LAI) ranging from 2.0 to 4.0 for Rhyncospermum jasminoides and from 1.5 to 3.5 for Pandorea jasminoides variegated throughout the year. LAI was measured with a AccuPAR PAR/LAI Ceptometer (model LP-80, Decagon Devices Inc., Pullman, WA, USA) once plants were fully developed.

Several climatic parameters concerning the ambient conditions and the walls behind the plants were collected at the experimental field from June 2014. These parameters were: the temperature of the plaster on the external surface of the walls, the external air temperature, the solar radiation on a horizontal and on a vertical plane, the relative humidity of the external air, the wind velocity and direction.

Data were measured with a frequency of $60 \mathrm{~s}$; afterward they were averaged every $15 \mathrm{~min}$ and stored by means of a data logger (CR10X, Campbell, Logan, USA). The temperature of the external plaster surfaces was measured by thermistors (Tecno.EL s.r.l. Formello, Rome, Italy). Hygroclip-S3 sensors (Rotronic, Zurich, Switzerland) measured the temperature and the relative humidity of the external air. A pyranometer (model 8-48, Eppley Laboratory, Newport, RI, USA) was used for measuring both the solar radiation incident on a horizontal and on a vertical plane in the wavelength range $0.3-3.0 \mathrm{~mm}$. The wind velocity and direction were measured by means of a Young Wind Sentry anemometer (Young Company, Traverse City, MI, USA). The sensors were shielded from solar radiation.

The analysis of variance (ANOVA) was developed with the CoStat software (CoHort Software, Monterey, CA, USA). It was aimed to identify significant differences between the temperature data on the walls.

The multiple linear regression technique was used to define the linear dependence of the difference of the external surface temperature between the control wall and the green façade, the dependent variable, on the independent parameters, known as 'predictors' [29]-[30].

The regression models can diversify with the kind of data (field data or simulated data), the data time interval and the forecasting temporal horizon [30]. Consequently, the experimental data were grouped into time slots having a similar solar radiation on a horizontal surface $\left(\mathrm{I}_{\text {hor }}\right)$.

The external climate parameters, as external air temperature and relative humidity, horizontal and vertical solar radiation, wind velocity and direction, are the predictors. The difference of the external surface temperature between the control wall and the green façade $\left(Y_{t}\right)$ was expressed by the following equation:

$$
\begin{aligned}
Y_{t}= & \beta_{0}+\beta_{1} Y_{t-1}+\beta_{2} X_{1, t}+\beta_{3} X_{1, t-1}+\beta_{4} X_{2, t}+\beta_{5} X_{2, t-1}+\beta_{6} X_{3, t}+\beta_{7} X_{3, t-1} \\
& +\beta_{8} X_{4, t}+\beta_{9} X_{4, t-1}+\beta_{10} X_{5, t}+\beta_{11} X_{5, t-1}+\beta_{12} X_{6, t}+\beta_{13} X_{6, t-1}+\varepsilon_{t} .
\end{aligned}
$$

In eqn (1) $Y_{t}$ and $Y_{t-1}$ are the difference of the external surface temperature at time $t$ and $t-1$, where $t$ stands for the quarters of hours falling within the period considered. $X_{i, t}$ and $X_{i, t-1}$ stand for the predictor variables at time $t$ and at time $t-1$, respectively: $X_{1, t}$ and $X_{1, t-1}$ are the external air temperature, $X_{2, t}$ and $X_{2, t-1}$ are the solar radiation on a horizontal surface, $X_{3, t}$ and $X_{3, t-1}$ are the relative humidity of the external air, $X_{4, t}$ and $X_{4, t-1}$ are the wind velocity, $X_{5, t}$ 
and $X_{5, t-1}$ are the wind direction, and $X_{6, t}$ and $X_{6, t-1}$ are the solar radiation on a vertical surface. $\beta_{i}$ are the coefficients of the regression model, $i=0, \ldots, 13 . \beta_{0}$ is the intercept and $\varepsilon_{t}$ is an error value that estimates the difference between the observed data and the predicted data.

Equation (1) was applied for predicting the temperature difference values. The fitted/predicted value and the parameters of the estimated regression model where determined with the Least Squares Method using the Regression Tool in Excel's Data Analysis add-in. The multiple linear regression model was fitted on the data gathered during August 2015. The model was used for predicting the thermal performance of the green façades during August 2016.

\section{RESULTS AND DISCUSSION}

During August 2015 the external air temperature values at the experimental field ranged from $18.3^{\circ} \mathrm{C}$ to $40.2^{\circ} \mathrm{C}$. The average external air relative humidity was $64.2 \%$ and the average wind velocity was $2.0 \mathrm{~ms}^{-1}$. The monthly value of cumulative solar radiation was $643.4 \mathrm{MJ} \mathrm{m}^{-2}$ and $343.9 \mathrm{MJ} \mathrm{m}^{-2}$ on a horizontal and on a vertical plane, respectively.

During August 2016 the field was characterized by values of the external air temperature ranging from $16.2^{\circ} \mathrm{C}$ to $39.2^{\circ} \mathrm{C}$. The average external air relative humidity was $62.5 \%$ and the average wind velocity was $2.2 \mathrm{~ms}^{-1}$. The monthly value of cumulative solar radiation was 663.4 $\mathrm{MJ} \mathrm{m}^{-2}$ and $333.6 \mathrm{MJ} \mathrm{m}^{-2}$ on a horizontal and on a vertical plane, respectively.

Time slots were defined, in accordance of the characteristics of the study climatic area:

- $\mathrm{I}_{\text {hor } 200}: \mathrm{I}_{\text {hor }}<200 \mathrm{~W} \mathrm{~m}^{-2}$, assessed during the time period 00:00-06:30 or 17:45-23:45;

- $\mathrm{I}_{\text {hor } 200-400}: 200 \leq \mathrm{I}_{\text {hor }}<400 \mathrm{~W} \mathrm{~m}^{-2}$, assessed during the time period 06:45-07:30 or 16:4517:30;

- $\mathrm{I}_{\text {hor } 400-600}: 400 \leq \mathrm{I}_{\text {hor }}<600 \mathrm{~W} \mathrm{~m}^{-2}$, assessed during the time period 07:45-08:45 or 15:4516:30;

- $\mathrm{I}_{\text {hor } 600-800}: 600 \leq \mathrm{I}_{\text {hor }}<800 \mathrm{~W} \mathrm{~m}^{-2}$, assessed during the time period 09:00-10:15 or 14:00 15:30;

- $\mathrm{I}_{\text {hor } 800}: \mathrm{I}_{\text {hor }} \geq 800 \mathrm{~W} \mathrm{~m}^{-2}$, assessed during the time period 10:30-13:45.

A statistical model was developed for each time range and for each of the two green façades. The regression models were developed by using the data recorded during August 2015 for Rhyncospermum jasminoides and for Pandorea jasminoides variegated. The subscript $t$ in eqn (1) is $t=1, \ldots, 2976$. Tables $1-2$ show the regression coefficients. Quality analysis parameters were evaluated for each model (Tables 1-2). These parameters are the coefficient of determination $\mathrm{R}^{2}$, the adjusted coefficient of determination $\mathrm{R}_{\mathrm{adj}}{ }^{2}$ and the Root-mean-square error (RMSE). $\mathrm{R}^{2}$ and $\mathrm{R}_{\mathrm{adj}}{ }^{2}$ indicate a goodness of the fit to the training data for each model. The RMSE values show that the dispersion of the data around the regression line is low.

The regression coefficients cannot be compared to each other, because they are related to different unit of measurement. A positive regression coefficient means that an increase in the value of the related predictor will increase the temperature difference.

The regression coefficients $\hat{\beta}_{2}$ and $\hat{\beta}_{3}$, which are related to the external air temperature predictor, are positive and negative. Thus, the contribution of the predictors $X_{1, t}$ and $X_{1, t-1}$ partially compensate each other. Their contribution is not significant for $\mathrm{I}_{\text {hor }} 400-600^{*}{ }_{\hat{\beta}}$

The coefficients $\hat{\beta}_{12}$ and $\hat{\beta}_{13}$ are characterised by absolute values higher than $\hat{\beta}_{4}$ and $\hat{\beta}_{5}$, when all exist. This shows a greater dependence of the difference of the external surface temperature between the control wall and the green façades on the vertical than horizontal solar radiation. 


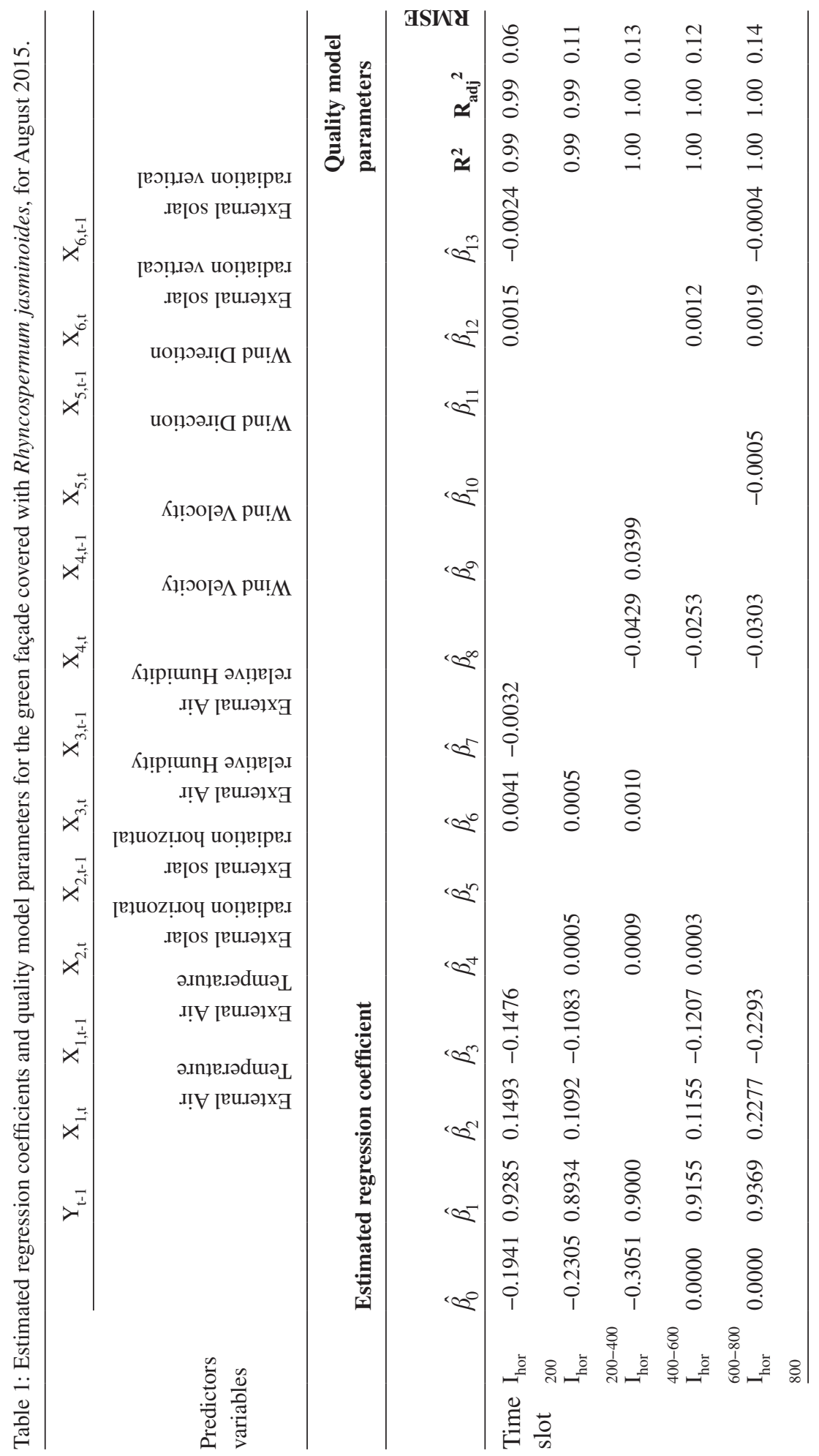




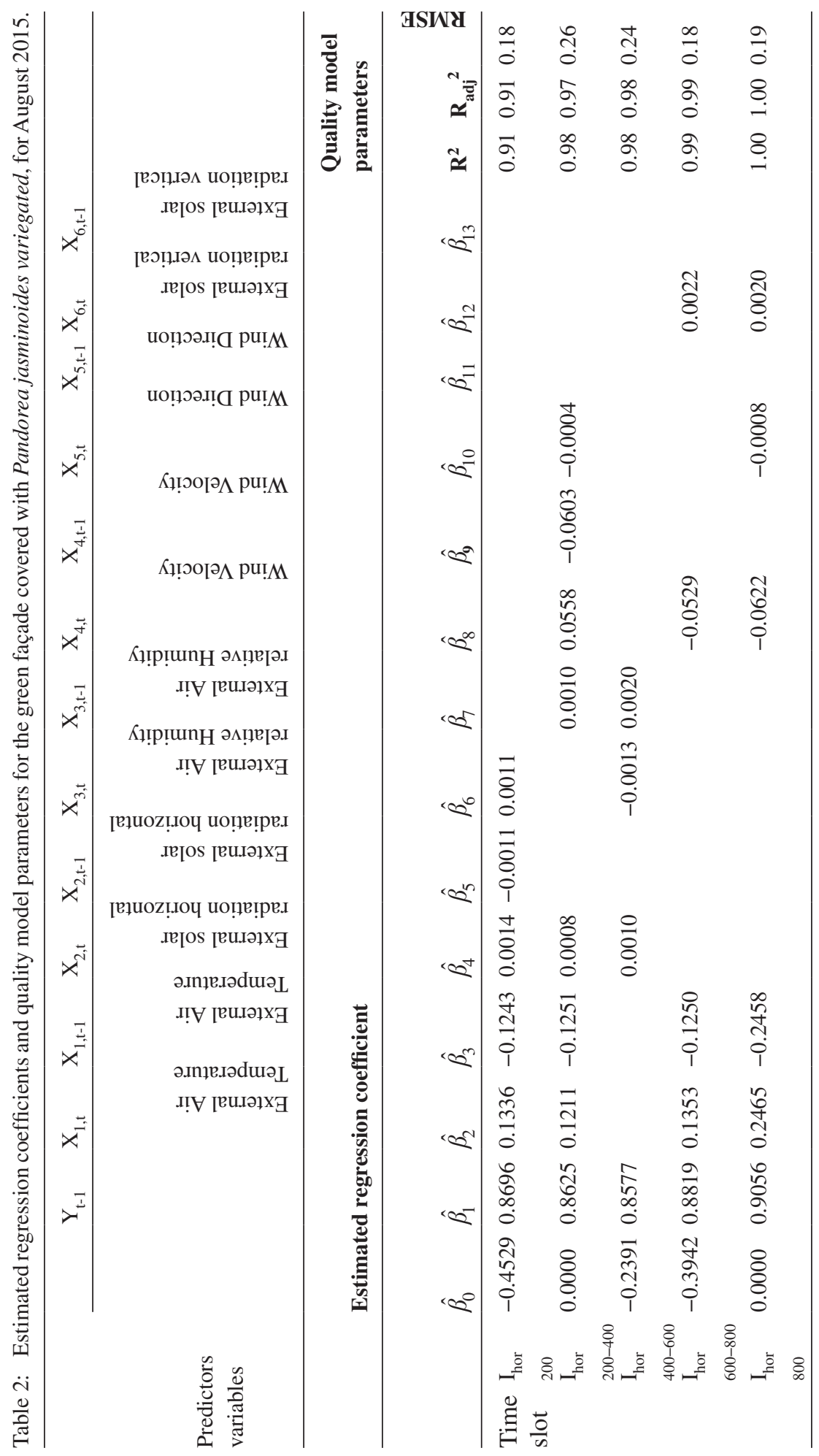


In relation to the external air relative humidity, the regression coefficients $\hat{\beta}_{6}$ and $\hat{\beta}_{7}$ are not significant for $\mathrm{I}_{\text {hor } 600-800}$ and for $\mathrm{I}_{\text {hor } 800}$. The dependence on the wind variable is expressed by the $\hat{\beta}_{8}$ and $\hat{\beta}_{9}$ (wind velocity) and $\hat{\beta}_{10}$ and $\hat{\beta}_{11}$ (wind direction). No dependence on the wind characteristics results for $\mathrm{I}_{\text {hor } 200}$ for both green façades.

Each model, which was developed using data concerning August 2015 data, was then applied to predict the performance of the green façades in August 2016. Figures 2 and 3 show, as a result, the difference between the temperature of the external surface on the control wall and on the green walls observed during the experimental test and the difference of temperature values predicted with the regression models, during 25-31 August 2016.

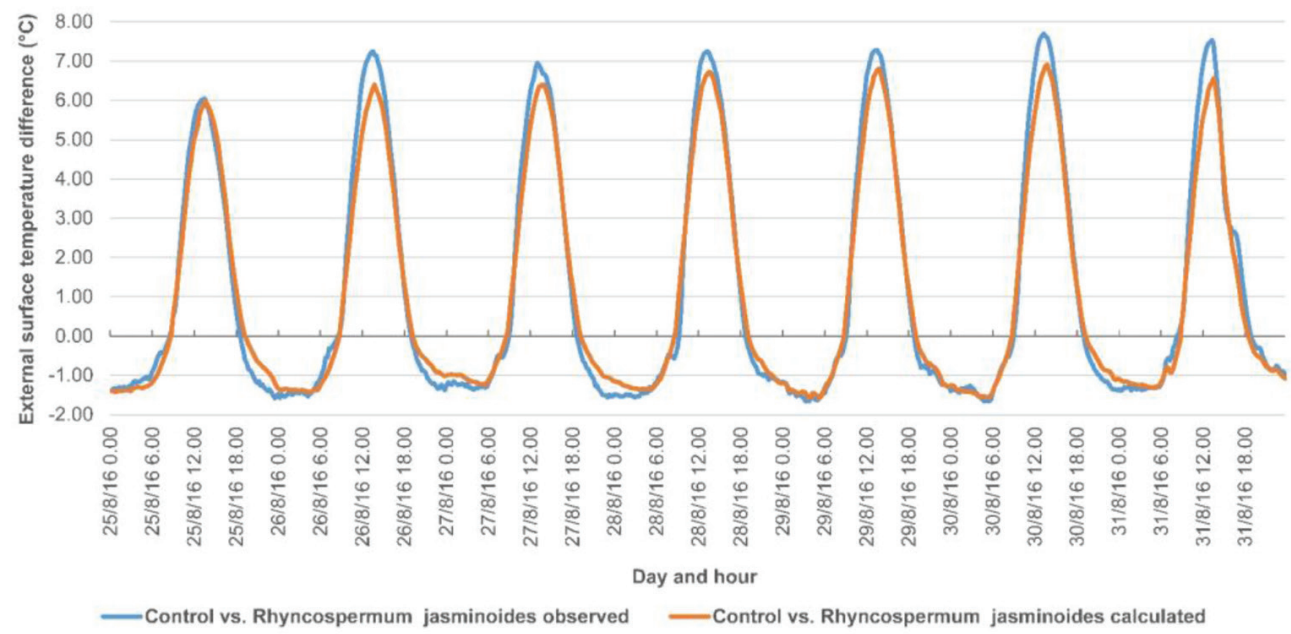

Figure 2: Difference of the external surface temperature between the control wall and the green façade covered with Rhyncospermum jasminoides: data observed at the experimental field and values calculated by using the regression models; 25-31/08/2016.

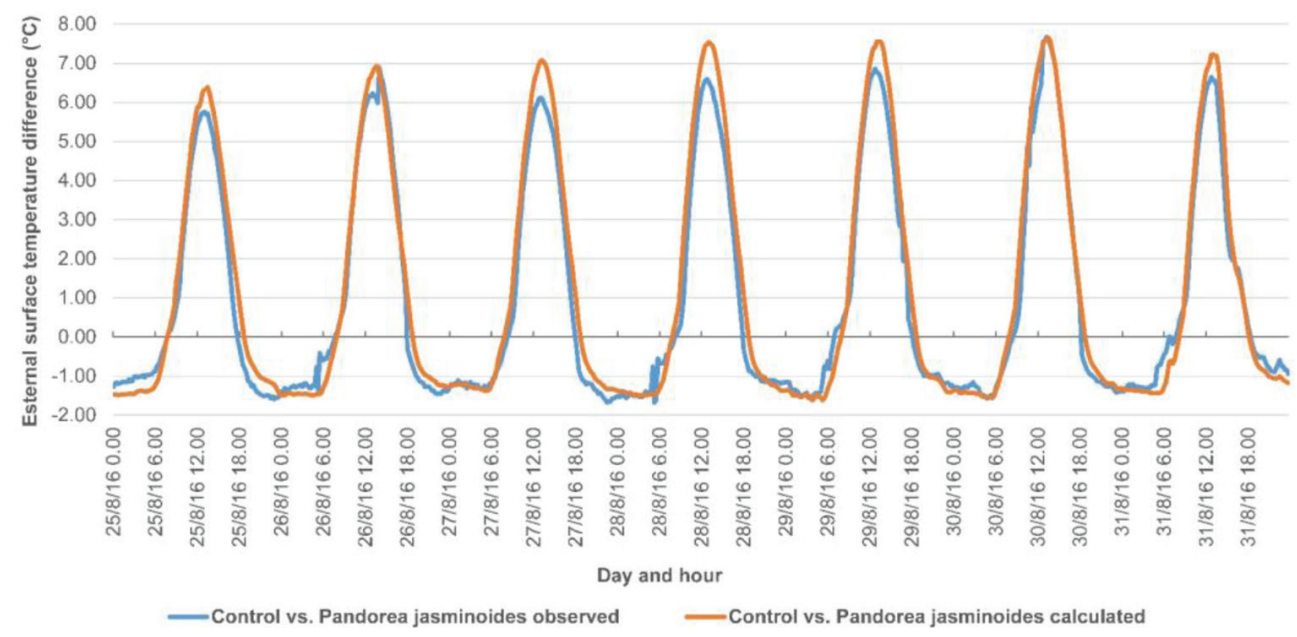

Figure 3: Difference of the external surface temperature between the control wall and the green façade covered with Pandorea jasminoides variegated: data observed at the experimental field and values calculated by using the regression models;25-31/08/2016. 
The models show a good predicting performance. A one-way ANOVA analysis at a $95 \%$ probability level was developed for the selected days of the testing month. It evaluated the mean values of the experimental data and the calculated data; no statistically significant differences were found for both the green façades.

The minimum difference between the external surface temperature of the control wall and the green façade covered with Rhyncospermum jasminoides (Fig. 2) was $-1.66^{\circ} \mathrm{C}$ and $-1.58^{\circ} \mathrm{C}$ for the experimental values and the predicted values, respectively. The maximum difference was $7.69^{\circ} \mathrm{C}$ and $6.91{ }^{\circ} \mathrm{C}$ for the experimental values and the predicted values, respectively.

The minimum difference between the external surface temperature of the control wall and the green façade covered with Pandorea jasminoides variegated (Fig. 3) was $-1.68^{\circ} \mathrm{C}$ and $-1.62^{\circ} \mathrm{C}$ for the experimental values and the predicted values, respectively. The maximum difference was $7.67^{\circ} \mathrm{C}$ and $7.64^{\circ} \mathrm{C}$ for the experimental values and the predicted values, respectively.

\section{CONCLUSIONS}

Vertical greenery popularity is growing due to their high potential in being used as a sustainable solution for improving the thermal performance of building envelopes in the sector of residential and rural constructions. In summer in Mediterranean climate conditions, the thermal performance of the green façades still needs further research study and in particular experimental data on long periods. The assessment of the plants suitable for the Mediterranean context and of their performance is necessary for choosing the most efficient solution.

This study explores the thermal performance of two green façades that were built in Bari, South Italy. Rhyncospermum jasminoides and Pandorea jasminoides variegated were selected for covering the experimental walls. The application of the green cover allowed reducing the daylight temperatures on the external surface of the shielded walls during warm days. The experimental data were used for developing a multiple regression equation regarding the dependence of the difference of external surface temperature between the green façades and the control wall and the weather conditions. The model was trained on August 2015 data. The predictive model can be useful for predicting the external surface temperature reduction by the green cover. Its predicting ability was tested on August 2016. The model shows a good predicting performance, resulting a useful tool in comparing the efficacy of the two vertical greenery solutions in similar Mediterranean climatic contexts.

\section{ACKNOWLEDGEMENTS}

The contribution to programming and conducting this research must be equally shared between the Authors.

The present work has been carried out under the 'Piano triennale della Ricerca 2015-2017 nell' ambito del Sistema Elettrico Nazionale, Progetto D.1 'Tecnologie per costruire gli edifici del futuro', Research activity: "Analisi di tecniche di raffrescamento sostenibili applicabili in edifici civili e in edifici serra" Piano Annuale di Realizzazione (PAR) 2017', Accordo di Programma Ministero dello Sviluppo Economico - ENEA funded by the Italian Ministry of Economic Development.

\section{REFERENCES}

[1] Norton, B.A., Coutts, A.M., Livesley, S.J., Harris, R.J., Hunter, A.M. \& Williams, N.S.G., Planning for cooler cities: A framework to prioritise green infrastructure to mitigate high temperatures in urban landscapes. Landscape and Urban Planning, 134, pp. 127-138, 2015. https://doi.org/10.1016/j.landurbplan.2014.10.018 
[2] Pérez, G., Coma, J., Martorell, I. \& Cabeza, L.F., Vertical Greenery Systems (VGS) for energy saving in buildings: A review. Renewable and Sustainable Energy Reviews, 39, pp. 139-165, 2014. https://doi.org/10.1016/j.rser.2014.07.055

[3] Tan, C.L., Wong N.H. \& Jusuf, S.K., Effects of vertical greenery on mean radiant temperature in the tropical urban environment. Landscape and Urban Planning, 127, pp. 52-64, 2014. http://dx.doi.org/10.1016/j.landurbplan.2014.04.005

[4] Vox, G., Blanco, I., Campiotti, C.A., Giagnacovo G. \& Schettini, E., Vertical green systems for buildings climate control. Proceedings of the 43rd International Symposium - Actual Tasks on Agricultural Engineering, Sveučilište u Zagrebu, Agronomski fakultet, Zavod za mehanizaciju poljoprivrede. Opatija, Croatia, 24-27/02/2015, pp. 723-732, 2015.

[5] Vox, G., Blanco, I., Fuina, S., Campiotti, C.A., Scarascia Mugnozza, G. \& Schettini, E., Evaluation of wall surface temperatures in green facades. Proceedings of the Institution of Civil Engineers - Engineering Sustainability, 170(6), pp. 334-344, 2017. https://doi.org/10.1680/jensu.16.00019

[6] Berardi, U., Ghaffarianhoseini, A.H. \& Ghaffarian Hoseini, A., State-of-the-art analysis of the environmental benefits of green roofs. Applied Energy, 115, pp. 411-428, 2014. http://dx.doi. org/10.1016/j.apenergy.2013.10.047

[7] Fernandez-Cañero, R., Emilsson, T., Fernandez-Barba, C. \& Herrera Machuca, M.A., Green roof systems: a study of public attitudes and preferences in southern Spain. Journal of Environmental Management, 128, pp. 106-115, 2013. http://dx.doi.org/10.1016/j. jenvman.2013.04.052

[8] Santamouris, M., Cooling the cities - a review of reflective and green roof mitigation technologies to fight heat island and improve comfort in urban environments. Solar Energy, 103, pp. 682-703, 2012. http://dx.doi.org/10.1016/j.solener.2012.07.003

[9] Cheng, C.Y., Cheung, K.K.S. \& Chu, L.M., Thermal performance of a vegetated cladding system on facade walls. Building and Environment, 45(8), pp. 1779-1787, 2010. https://doi.org/10.1016/j.buildenv.2010.02.005

[10] Jim, C.Y. \& Tsang, S.W., Biophysical properties and thermal performance of an intensive green roof. Building and Environment, 46(6), pp. 1263-1274, 2011. https://doi.org/10.1016/j.buildenv.2010.12.013

[11] Köhler, M. \& Poll, P.H., Long-term performance of selected old Berlin greenroofs in comparison to younger extensive greenroofs in Berlin. Ecological Engineering, 36(5), pp. 722-729, 2010. https://doi.org/10.1016/j.ecoleng.2009.12.019

[12] Perini, K., Ottelé, M., Fraaij, A.L.A., Haas E.M. \& Raiteri, R., Vertical greening systems and the effect on air flow and temperature on the building envelope. Building and Environment, 46(11), pp. 2287-2294, 2011. https://doi.org/10.1016/j.buildenv.2011.05.009. https://doi.org/10.1016/j.buildenv.2011.05.009

[13] Safikhani, T., Abdullah, A.M., Ossen, D.R. \& Baharvand, M., A review of energy characteristic of vertical greenery systems. Renewable and Sustainable Energy Reviews, 40, pp. 450-462, 2014. https://doi.org/10.1016/j.rser.2014.07.166

[14] Gago, E.J., Roldan, J., Pacheco-Torres R. \& Ordóñez, J., The city and urban heat islands: A review of strategies to mitigate adverse effects. Renewable and Sustainable Energy Reviews, 25, pp. 749-758, 2013. https://doi.org/10.1016/j.rser.2013.05.057

[15] Cameron, R.W.F., Taylor J.E. \& Emmett, M.R., What's 'cool' in the world of green façades? How plant choice influences the cooling properties of green walls. Building and Environment, 73, pp. 198-207, 2014. https://doi.org/10.1016/j.buildenv.2013.12.005

[16] Yang, F., Yuan, F., Qian, F., Zhuang, Z. \& Yao J., Summertime thermal and energy performance of a double-skin green facade: A case study in Shanghai. Sustainable Cities and Society, 39, pp. 43-51, 2018. https://doi.org/10.1016/j.scs.2018.01.049 
[17] Raji, B., Tenpierik, M.J. \& van den Dobbelsteen, A., The impact of greening systems on building energy performance: A literature review. Renewable and Sustainable Energy Reviews, 45, pp. 610-623, 2015. https://doi.org/10.1016/j.rser.2015.02.011

[18] Medl, A., Stangl, R. \& Florineth, F., Vertical greening systems - A review on recent technologies and research advancement. Building and Environment, 125, pp 227-239, 2017. ISSN 0360-1323. https://doi.org/10.1016/j.buildenv.2017.08.054

[19] Pérez-Urrestarazu, L., Fernández-Cañero, R., Franco-Salas A. \& Egea, G., Vertical Greening Systems and Sustainable Cities. Journal of Urban Technology, 22(4), pp. 65-85, 2016. https://doi.org/10.1080/10630732.2015.1073900

[20] Lin, H., Xiao, Y. \& Musso, F., Shading Effect and Heat Reflection Performance of Green Façade in Hot Humid Climate Area: Measurements of a Residential Project in Guangzhou, China. IOP Conference Series: Earth and Environmental Science, 146, p. 012006, 2018. https://doi.org/10.1088/1755-1315/146/1/012006

[21] Kontoleon, K.J. \& Eumorfopoulou, E.A., The effect of the orientation and proportion of a plant-covered wall layer on the thermal performance of a building zone. Building and Environment, 45, Suppl. 5, pp. 1287-1303, 2010. http://dx.doi.org/10.1016/j. buildenv.2009.11.013

[22] Giordano, R., Montacchini, E., Tedesco S. \& Perone, A., Living Wall Systems: A Technical Standard Proposal. Energy Procedia, 111, pp. 298-307, 2017. http://dx.doi. org/10.1016/j.egypro.2017.03.093

[23] Eumorfopoulou, E.A., \& Kontoleon, K.J., Experimental approach to the contribution of plant-covered walls to the thermal behaviour of building envelopes. Building and Environment, 44(5), pp. 1024-1038, 2009. https://doi.org/10.1016/j. buildenv.2008.07.004

[24] Campiotti, C.A., Schettini, E., Alonzo, G., Viola, C., Bibbiani, C., Scarascia Mugnozza, G., Blanco, I. \& Vox, G., Building green covering for a sustainable use of energy. Journal of Agricultural Engineering, 44(2s), pp. 253-256, 2013. https://doi.org/10.4081/ jae.2013.292

[25] Blanco, I., Schettini, E., Scarascia Mugnozza, G., Campiotti, C.A., Giagnacovo, G. \& Vox, G., Vegetation as a passive system for enhancing building climate control. Acta Horticulturae, 1170, pp. 555-562, 2017. https://doi.org/10.17660/actahortic.2017.1170.69

[26] Vox, G., Blanco, I. \& Schettini, E., Green façades to control wall surface temperature in buildings. Building and Environment, 129, pp. 154-166, 2018. https://doi.org/10.1016/j. buildenv.2017.12.002

[27] Hunter, A.M., Williams, N.S.G., Rayner, J.P., Aye, L., Hes, D. \& Livesley, S.J., Quantifying the thermal performance of green façades: a critical review. Ecological Engineering, 63, pp. 102-113, 2014. http://dx.doi.org/10.1016/j.ecoleng.2013.12.021

[28] UNI EN 1745 2012. Masonry and masonry products - Methods for determining thermal properties. UNI - Ente Nazionale Italiano di Unificazione - Italian Organization for Standardization; IT.

[29] Fumo, N. \& Rafe Biswas, M.A., Regression analysis for prediction of residential energy consumption. Renewable and Sustainable Energy Reviews, 47, pp. 332-343, 2015. DOI: 10.1016/j.rser.2015.03.035 https://doi.org/10.1016/j.rser.2015.03.035

[30] Yildiz, B., Bilbao J.I. \& Sproul, A.B., A review and analysis of regression and machine learning models on commercial building electricity load forecasting. Renewable and Sustainable Energy Reviews, 73, pp. 1104-1122, 2017. https://doi.org/10.1016/j. rser.2017.02.023 